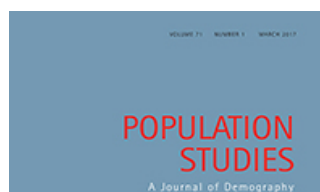

Population Studies

\title{
Sociology as a Population Science
}

\section{John Cleland}

To cite this article: John Cleland (2017) Sociology as a Population Science, Population Studies, 71:1, 133-134, DOI: 10.1080/00324728.2016.1201269

To link to this article: http://dx.doi.org/10.1080/00324728.2016.1201269

曲 Published online: 17 Feb 2017.

Submit your article to this journal $\pi$

III Article views: 73

Q View related articles $\sqsubset$

View Crossmark data $₫$ 


\section{Book reviews}

Sociology as a Population Science. 2016. By JOHN H. GOLDTHORPE. Cambridge: Cambridge University Press. Pp. ix $+168 . £ 14.99$ or US\$24.99 paperback. ISBN: 978-1-107-56731-3.

John Goldthorpe has had a long and distinguished career as a quantitative sociologist. He has contributed more than anyone to an understanding of social mobility in Britain. In this concise book, he presents his vision of sociology as a population science, its disciplinary boundaries, and its methods of enquiry. Most of what he writes will be highly congenial to social demographers and it is no coincidence that Goldthorpe's two most important mentors were Otis Dudley Duncan and David Glass, who taught him at the London School of Economics. Duncan, a pioneering quantitative sociologist, used a population perspective in his research and even wrote on demographic issues with Philip Hauser, a colleague at the Population Research and Training Center, University of Chicago (Hauser and Duncan 1959). Glass, a demographer, made important contributions to the study of social mobility in addition to his more formal demographic work (e.g., Glass 1954; Glass and Eversley 1965).

Goldthorpe's vision of his discipline is an individualistic one: individual action, despite constraints, retains autonomy and is accorded causal primacy. From individual variability regularities emerge, and the mandate of sociology is to identify and explain these probabilistic regularities within heterogeneous populations and sub-populations. This requires statistical analyses of individual data sets, typically derived from large representative sample surveys. Multivariate analysis is needed to distinguish valid from spurious regularities but falls short of establishing causation.

While statistical analysis of data sets makes regularities visible, causal explanation seeks to make them transparent by specifying the mechanisms through which they arise and are maintained. The hypothesized mechanisms need to draw on theory, be adequate or sufficient to generate the regularity and, most importantly, be open to empirical confirmation or rejection. Goldthorpe identifies two main approaches to mechanism-based explanation. The first, associated with 'analytical sociology', is to draw upon a catalogue or toolkit of social mechanisms, one example being social diffusion mechanisms (e.g., Palloni 2001). While this approach has the advantage of allowing theoretical integration across substantive domains, it has the inherent danger of prioritizing the mechanisms themselves and searching for examples that best illustrate their explanatory power rather than seeking to account for observed population regularities. Thus, the effect of causes rather than the causes of effects can become the main concern.

The second main approach, less developed than the first but clearly favoured by the author, starts with the observed regularity and seeks to explain it, while accepting that more than one prime social mechanism may operate. Simply appealing to values or norms is inadequate. What is required is an account of individual actions based on an assumption of bounded and subjective rationality, which may or may not conform to social norms. Three possible ways of establishing causal mechanisms are outlined: direct observation through intensive case studies; the more indirect way of showing that the hypothesized mechanisms imply other population regularities that can then be empirically verified; and, less commonly, in an experimental way. A fourth method, which is briefly mentioned in a footnote, is agent-based computational modelling. This comprises the construction of a model of individual behaviour that is capable of giving rise to the observed regularity. The example here is a model able to reproduce observed regularities in age at first marriage (Todd et al. 2005). However, this method, while adequate, cannot demonstrate that the mechanisms embodied in the model do in fact bring about the regularity of interest.

In the concluding chapter Goldthorpe considers the relationship of sociology to adjacent disciplines. He sees great potential for closer collaboration between sociology, demography, and social epidemiology, and envisages research centres in which sociologists, demographers and social epidemiologists would be brought together and in which research would be pursued on such lines that disciplinary boundaries would be in large part 
transcended' (p. 132). In contrast he affirms a clear distinction between history, concerned primarily with explanations of particular events, and sociology concerned with regularities in events. Despite the emergence of behavioural economics and the individualistic paradigm advanced in this book, he is sceptical of closer relationships between sociology and economics. In his view mainstream economists remain largely uninterested in how everyday decisions are actually made and unwilling to subject strongly held theories to empirical tests.

Goldthorpe is well aware that this book will offend many sociologists because his vision implies a marked shrinking of the current diverse sociological domain. But if sociology is to be accepted and advance as a science, it should abandon much of its plurality. He quotes Mies van der Rohe in concluding that 'less would be more' (p. 127).

This is an engaging and thought-provoking book that, in conjunction with similar arguments advanced by demographers (e.g., Billari 2015) and alternative approaches to causation in population studies (e.g., Ni Bhrolchain and Dyson 2007), will be useful to social demographers in providing a clearer conceptual and methodological foundation for their research.

\section{References}

Billari, Francesco. 2015. Integrating macro- and micro-level approaches in the explanation of population change, Population Studies 69(Suppl 1): S11-S20.

Glass, D. V. 1954. Social Mobility in Britain. London: Routledge, Kegan, Paul.

Glass, D. V. and D. E. C. Eversley (eds). 1965. Population in History. Chicago: Aldine.

Hauser, P. M. and O. D. Duncan (eds). 1959. The Study of Population: An Inventory and Appraisal. Chicago: University of Chicago Press.

Ni Bhrolchain, Maire and Tim Dyson. 2007. On causation in demography: Issues and illustrations, Population and Development Review 33(1): 1-36.

Palloni, Alberto. 2001. Diffusion in sociological analysis, in John B. Casterline (ed.), Diffusion Processes and Fertility Transition. Washington, DC: National Academy Press, pp. 66-114.

Todd, Peter M., Francesco C. Billari, and Jorge Simao. 2005. Aggregate age-at-marriage patterns from individual mate-search heuristics, Demography 42(3): 559-574.

(C) 2017 John Cleland London School of Hygiene \& Tropical Medicine john.cleland@lshtm.ac.uk http://dx.doi.org/10.1080/00324728.2016.1201269
The Life Project: The Extraordinary Story of Our Ordinary Lives. 2016. By HELEN PEARSON. London: Allen Lane. Pp. $\mathrm{x}+399$. £20.00. ISBN: 978-1-846-14826-2.

This is an extraordinarily well-told story about the British Birth Cohorts and their sometimes rocky road to international renown. It starts with a survey, sponsored by the Population Investigation Committee (based at the London School of Economics), of all births across Great Britain in one week of 1946. The story, but not the survey, ends as that cohort reaches the age of 70 . Four other major studies also continue to follow their members' lives. (A sixth, which would have been the biggest of them all, suffered a sudden death in infancy in 2015.) These studies have been accumulating a mass of data on the health, and social and economic experience of 'ordinary people' as their lives unfold. The book's prose style is aimed at a general reader:

When the first birth cohort was recruiting, all the mothers took part because they felt an obligation to do their bit for the country. By the time of the fifth [Millennium], that sentiment seemed as laughably out of date as rationing and hand-knitted vests. (p. 265)

The gripping and well-crafted narrative is enlivened by a few biographical vignettes of cohort members, who consented to their inclusion, and some anecdotes about study leaders. The author's skills as a science journalist are applied to non-technical explanations of such topics as the Foetal Origins Hypothesis, epigenetics, Mendelian randomization, induced pluripotent stem cells, regression to the mean, and relative vs. absolute social mobility.

Readers of this journal may be aware of the role of David Glass in the design of the early stages of the 1946 cohort study, and that of James Douglas, who took the project forward. The concern about the country's low fertility, which had largely prompted the study, was overtaken by the unanticipated postwar baby boom, but the study's findings about the cost and pain of childbirth helped improve maternity services in the soon-to-be-introduced National Health Service. The study also established a baseline of social inequalities that were still evident when this longest running cohort entered old age. The cohort studies which came later continued to chart social differences in life chances.

The next two studies of cohorts, one of children born in one week of 1958 and the other in one week of 1970, with approximately 17,000 births 